\title{
Revisiting Financial (Accounting) Literacy: A Comparison Of Audit Committee Members And Business Students
}

\author{
Don E. Giacomino, CPA, Marquette University, USA \\ Joseph Wall, MBA, Carthage College, Managing Director, Ideas in Motion, LLC, USA \\ Michael D. Akers, CPA, CMA, CFE, CIA, Marquette University, USA
}

\begin{abstract}
While financial literacy is important for an audit committee in discharging its duties there is no authoritative guidance or definition and limited empirical research as to what constitutes financial literacy of audit committees and business students. Coates et al. conducted a study that examined the financial literacy of corporate board members and MBA students at the University of Chicago using an instrument developed by Schipper and Weil. Their findings suggest that both groups lack the appropriate level of financial literacy. This paper extends that research by using the same instrument to examine the financial literacy of undergraduate accounting finance students at a private Midwestern university. Our findings indicate the undergraduate students also lack financial literacy. Caution should be used in interpreting these results since there is no consensus definition of financial literacy within the accounting profession
\end{abstract}

Keywords: financial literacy, audit committee, corporate governance, financial expert, literacy testing

\section{MEASURING FINANCIAL (ACCOUNTING) LITERACY: AUDIT COMMITTEE MEMBERS AND BUSINESS STUDENTS}

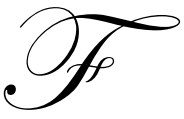

inancial literacy (or lack thereof) has played a key role in the success and failure of our nation's public companies for the past century. Ever since the implementation of the Exchange Act by the SEC in 1934, public corporations have been charged with ensuring the accuracy of their financial statements. Since the early 1940s, the Commission, along with the auditing and corporate communities, has had a continuing interest in promoting effective and independent audit committees. As early as 1940, the Commission encouraged the use of audit committees composed of independent directors. An audit committee comprised of independent directors is better situated to assess objectively the quality of the issuer's financial disclosure and the adequacy of internal controls than a committee that is affiliated with management.

Management may face market pressures for short-term performance and corresponding pressures to satisfy market expectations. These pressures could be exacerbated by the use of compensation or other incentives focused on short-term stock appreciation, which can promote self-interest rather than the promotion of long-term shareholder interest. An independent audit committee with adequate resources helps to overcome this problem and to align corporate interests with those of shareholders. Based primarily on the SEC's encouragement, Self Regulated Organizations (SROs) first adopted audit committee requirements in the 1970s. Subsequently, other organizations have expressed support for strong, independent audit committees, including the National Commission on Fraudulent Financial Reporting, also known as the Treadway Commission (National Commission on Fraudulent Financial Reporting, 1987), the General Accounting office which issued "CPA Audit Quality: Status of Actions Taken to Improve Auditing and Financial Reporting of Public Companies," (GAO, 1989) and the Blue Ribbon Committee on Improving the Effectiveness of Corporate Audit Committees (1999). The Treadway Commission was sponsored by the American Institute of Certified Public Accountants, the American Accounting Association, the Financial Executives Institute (now Financial Executives International), the Institute of Internal Auditors and the National 
Association of Accountants. Collectively, these groups were known as the Committee of Sponsoring Organizations, or COSO.

\section{RELEVANT RESEARCH STUDIES}

Early studies indicate that directors were often found to be rubber stamp decision makers (Douglas, 1934) who did not understand the nature of many of their duties (Baker, 1945). In 1940, the Commission investigated the auditing practices of McKesson \& Robbins, Inc., and the Commission's ensuing report prompted action on auditing procedures by the auditing community. In the Matter of McKesson \& Robbins, the SEC Accounting Series Release (ASR) No. 19, Exchange Act Release No. 2707 (Dec. 5, 1940), Numerous debates over the proper balance of insiders versus outsiders and correct board composition ensued, with the majority of studies focusing on performance as it related to composition (Koontz, 1967, Baysinger, 1985, Barnhart, 1998, and countless others). For example, in 1972, the Commission recommended that companies establish audit committees composed of outside directors (See ASR No. 123 (Mar. 23, 1972). In 1974 and 1978, the Commission adopted rules requiring disclosures about audit committees (See Release No. 34-11147 (Dec. 20, 1974) and Release No. 34-15384 (Dec. 6, 1978). In focusing on the bigger picture items such as composition and balance, however, the financial comprehension of the individuals involved has been neglected.

An awareness of this issue has increased as evidenced by a working paper from Edinburgh (Song and Windram, 2000) which concludes that audit committee financial literacy reduces the probability of standards violations. Song and Windram (2000, p. 23) note, "This finding seems to justify the Blue Ribbon Committee's recommendation to institute a training program for audit committee members and indeed for non-executive directors".

Recent research (Coates et al. 2007) developed a classification to evaluate the financial literacy potential of audit committees and used an instrument developed by Schipper and Weil (Morse, 2004) to test the financial literacy of corporate board members and MBA students. Schipper and Weil (Morse, 2004) have examined and promoted directors' education through the programs they developed at the University of Chicago. Coates et al. (2007) conclude that audit committees need to improve financial literacy and that, for those companies where there is evidence of improvement of financial literacy by the audit committee; the organizations earned annualized abnormal returns compared to those organizations that didn't improve. This study also identifies other research that, although not directly testing financial literacy, examines audit committee issues such as expertise, independence and professional backgrounds.

\section{RECENT ACTION}

During the most recent ten years, Congress, the SEC, the NYSE, the NASD and the accounting profession have focused on the importance of financial literacy of audit committee members. In 1999, the Blue Ribbon Committee on Improving the Effectiveness of Corporate Audit Committees, convened by the NYSE and the NASD recommended that all publicly traded companies have an audit committee that includes at least three "financially literate" members. Although the committee does not offer a precise definition of financial literacy, it does say that "Such 'literacy' signifies the ability to read and understand fundamental financial statements, including a company's balance sheet, income statement, and cash flow statement (Blue Ribbon Committee, 1999, p. 26)."

In December 1999, the NYSE added a rule that companies shall have an audit committee that is made up of directors who are independent and financially literate and includes at least one financial expert. The rule does not define financial literacy, but it states that such qualification is interpreted by the company's Board of Directors in its judgment. Should the member not be financially literate, he/she must become financially literate within a reasonable period of time after his or her appointment to the audit committee.

The Sarbanes-Oxley Act (SOX) of 2002 requires that public companies have a "financial expert" on the Audit Committee, or explain why not. SOX has specific experience requirements for satisfying financial expertise, which is different from financial literacy. 
This paper extends recent research that measured the financial literacy of Board members and MBA students. Many current undergraduate and graduate students of business programs can expect to serve on audit committees of public firms; thus, one purpose is to test their current financial literacy. We begin with a definition of financial literacy; then, we examine research by Coates et. al. (2007) that measured the financial literacy of board members and MBA students at the University of Chicago. Later, we describe our study and present the results and we compare them with those of studies that tested financial literacy of corporate officers and board members. Last, we analyze what these studies tell us about the financial expertise of current and prospective board and audit committee members.

\section{FINANCIAL LITERACY DEFINED}

The Blue Ribbon Committee's definition was not specific with respect to technical knowledge. Coates et al. (2007) developed criteria for financial (accounting) literacy based on the mandatory disclosure of Critical Accounting Policies and Estimates section of an annual report. Their criteria focused on an understanding of the following items: business model, recognition and measurement of GAAP and IFRS, whether management's judgments and estimates are consistent with the business model and implications of management choices for potential manipulation of financial reporting. Such criteria are consistent with Hills and Weil (2004) proposed knowledge of financial information necessary for the audit committee to satisfactorily discharge its responsibilities. We use Weil's definition (Morse, 2004, p. 22) of financial literacy which includes the concept of accounting literacy:

Financial literacy is the ability to understand the important accounting judgments management makes, why management makes them, and how management can use those judgments to manipulate financial statements.

In a 2004 interview reported in the Harvard Business Review, Dr. Roman Weil observes "You'd think it would be a basic requirement on audit committees, but it's unbelievably scarce... How can an audit committee meet its oversight responsibility if it doesn't understand - think to ask about - these types of judgments and the extent to which management has used its discretion to affect reported income?" (Morse, p. 22).

\section{MEASURING FINANCIAL LITERACY OF CORPORATE OFFICERS, BOARD MEMBERS AND MBA STUDENTS}

Schipper and Weil (Morse, 2004) developed and have administered a multiple-choice quiz on financial (accounting) literacy to corporate board members for several years. The questions cover accounting and audit committee topics. Coates et al. (2007) administered the same instrument during the period 2002-2005 to over 1,400 attendees at executive education sessions (at the University of Chicago Graduate School of Business, Stanford Law School and Wharton) for board members and corporate officers. Almost all attendees were board members, CEOs or CFOs, or general counsel. Twenty percent of the attendees serve on audit committees. For the purpose of this paper, the attendees who completed the quiz are classified as "Directors". The 25-item quiz (Exhibit 1) contains 13 questions whose answers can be found in a basic accounting text for first-year MBA students. Of the 12 other questions, four deal with audit committee issues, and eight questions require clear understanding of some advanced topics that are currently pertinent for many companies. The advanced topics include: special purpose entities, use of reserves (two questions), restricting, issuance of share for I.O.U, stock options, derivatives, and income manipulation.

Some of the questions have more than one correct answer. Results are presented as both aggregated (the MC question is entirely correct or it is graded as wrong) and disaggregated (each choice is counted as a true-false item). Thus, for the disaggregated results, there are more than 25 correct answers.

The median score for the quiz was reported (Coates et al., 2007, p. 188) as eight correct (32\%) out of 25, with the score remaining constant over several years of testing. This score is on an aggregated basis, meaning that for questions with multiple correct answers, the respondent must identify all multiple answers to have the question considered as correct. 
Coates et al. (2007) also administered the financial literacy quiz to 155 MBA students at the University of Chicago. The MBA students answered only 13 of the items (questions) that appeared on the quiz taken by corporate officers and directors. Answers to those 13 questions can be found in a basic accounting text for first-year MBA students. Results for only the top $30 \mathrm{MBA}$ students were presented.

\section{Undergraduate Accounting and Finance Majors}

Accounting and finance majors at a private Midwestern university completed the financial literacy quiz. The quiz was not announced beforehand and the instructors did not prepare students specifically for the quiz. Most of the accounting majors were seniors in Auditing and/or Financial Statement Analysis and the finance majors were juniors and seniors in the Financial Statement Analysis course. In total, 49 students completed the quiz. The "UG" column shows results for these undergraduate students. To provide a better comparison with the top 30 MBA students at the University of Chicago, we show the undergraduate results for the top 30 undergraduate students. Please note that the pass rate of graduates of the accounting program of this institution ranked in the top 10 for three sections of the CPA exam for 2006 and in the top 3 for the two sections relevant for this study (Financial Accounting and Reporting-\#3 and Auditing-\#2).

\section{RESULTS}

Table 1 shows the undergraduate results with the Directors and MBA students' results from the Coates et al. (2007) study. Data, by question, are presented on an aggregated basis only with an overall average for each group. The topic for each question is classified as either (1) MBA (i.e., question based on first-year MBA accounting class information), (2) audit committee, or (3) advanced.

While the MBA students have a higher percentage correct, 53\%, as compared to the Directors, $32 \%$, and the undergraduate students, $29 \%$, the MBA students were only asked to respond to 13 of the 25 questions. Twelve of the twenty-five $(12 / 25=48 \%)$ questions answered by Directors and Undergraduate students had multiple correct answers while five of the thirteen $(5 / 13=38 \%$ answered by the MBA students had multiple answers. The overall correct response rate for each group is low. It is discouraging to note the low number of questions answered correctly by $50 \%$ of the respondents: Directors- 3 questions $(3 / 25=12 \%)$, MBA students- 8 questions $(8 / 13=62 \%)$ and Undergraduate students-5 questions $(5 / 25=20 \%)$. There are only three questions where every group scored more than 50\% (marketable securities, asset impairment and deferred revenue) and one question where two groups (MBA and undergraduate students) scored higher than $50 \%$ (equity method).

Table 2 provides results for the 13 items (questions) classified as MBA (i.e., the top 30 MBA students at the University of Chicago). Those MBA students answered only those 13 items as part of their final examination. As noted above five of those questions had multiple correct answers. The University of Chicago MBA students scored higher than the directors on the basis of overall average correct answers. However, Directors had higher scores on seven of the 13 topics. Overall, Directors scored an average of $42 \%$ on the 13 MBA questions, while the U. of Chicago MBA students averaged 52\%. One might be concerned about the validity of making these comparisons, since the MBA students were identified as the "top 30". However, the Directors "self-selected" for taking the quiz. Table 2 presents the results according to the Directors' scores in ascending order. Directors averaged below 30\% correct on four of the 13 topics; purchase commitments (9\%), deferred income taxes (16\%), operating leases (28\%) and LIFO accounting (28\%). They averaged over $50 \%$ on only three topics: marketable securities (59\%), asset impairment (72\%), and deferred revenue (74\%). They averaged between $33 \%$ and $48 \%$ on the remaining six topics. These low results can be explained in part by the fact that the scores were on an aggregated basis and the five topics on which they scored lowest had multiple correct answers. Chicago MBA students averaged over 50\% on eight of the 13 topics and below $30 \%$ on only one topic, deferred income taxes.

Overall, the MBA students scored higher (52\%) than the undergraduates (43\%) and the directors (42\%). Among the three groups, MBA students scored highest on six of the questions and lowest on five questions, while directors scored highest on four questions and lowest on two questions, and undergraduates scored highest on three questions and lowest on six questions. All three groups scored very low on the questions (multiple correct answers) related to purchase commitments and deferred taxes. They scored high on deferred revenue and asset impairment. 
Relative to the directors and undergraduates, the MBA students scored much higher on the equity method, LIFO accounting, the statement of cash flows and operating leases. Directors did well, comparatively, on asset impairments and undergraduates were stronger on deferred revenue and marketable securities. The findings suggest that all three groups lack the expected level of accounting knowledge that is expected from a basic MBA accounting course.

Table 3 shows results for the 12 non-MBA questions. These questions are classified as either "audit committee" or advanced (financial accounting) questions and included six questions with multiple answers. University of Chicago MBA students did not answer these questions, so the results are only for Directors' and Undergraduates. Whereas, the Directors scored an average of $42 \%$ and the Undergraduate students $43 \%$ correct on the MBA questions, both averaged only $21 \%$ on the 12 non-MBA questions. The Directors failed to score above $50 \%$ on any of those questions while the Undergraduate students scored above $50 \%$ for only one question (Stock Options-67\%). We find these results very surprising, and somewhat disturbing, given the fact that the topics relate to audit committee responsibilities and accounting issues that have played a major role in recent cases of financial improprieties. The two topics with the lowest correct averages for Directors are income manipulation (5\%) and restructuring (6\%) and for the students, restricting charges (3\%), materiality (7\%) and reserves (7\%). Many of the topics on this list relate to the concepts of earnings management and earnings quality. Specifically, they are; use of reserves (questions 18 and 19), stock options, special purpose entities, materiality and income manipulation.

Table 4 shows the results for each group (directors, MBA students and undergraduate students) on both aggregated and disaggregated bases. The median percent correct results for the MBA students are for only the 13 MBA items and the median percent correct results for the directors and undergraduates are for the 25 items. Consistent with the findings in Tables 1, 2, and 3 the MBA students correct response rate, aggregated and disaggregated, are higher than both the Directors and Undergraduate students. The correct response rate for the Directors and Undergraduate students are almost identical.

\section{ANALYSIS AND CONCLUSION}

Based on their results of testing the corporate officers and directors, Coates et al. (2007, p. 188) concluded:

The results point to financial illiteracy. The individual quiz takers, self-selected from larger audiences, are likely people more confident of their financial literacy than those who did not take the quiz. The people who took this quiz, likely the better half of our board member attendees, are not yet financially literate.

Our results suggest that the Undergraduate students are also financially illiterate. Caution should be exercised when considering these results. We agree with Schipper and Weil (Weil, 2006) that a low or high score might not indicate financial illiteracy or financial literacy for corporate board members but rather, this might be an indication that the individual deals with more specialized topics than the general topics examined in the survey. However, we would expect to see better results from the MBA and undergraduate students.

One of the major characteristics of the quiz is that 12 of the questions have multiple correct answers. When those questions are graded on an aggregate basis, each of the choices is treated as a separate true/false question. The respondent must get all of the four or five choices correct to be given credit for the question. Thus, the performance on most of these questions with multiple correct answers is well below the performance on the other questions. As shown in Table 1, eight of the nine questions with the lowest scores (directors) are those with multiple correct answers. In addition, eight of the ten questions with the lowest scores are "not" among the 13 questions that the MBA students answered.

The inclusion of questions with multiple correct answers makes it difficult to determine the respondent's level of knowledge about the topic being tested. Another complicating factor is that, in some cases, knowledge of more than one topic is being tested in a question. We do not have the results by question on a disaggregated basis for the Coates et. al. (2007) study; therefore, we are unable to make comparisons on a disaggregated basis for each question. However, Table 4 shows overall results for the three groups on both aggregated and disaggregated bases.

While it is possible that board members, MBA and undergraduate students aren't financially literature, it is entirely possible that the design of the survey instrument is a contributing factor to such conclusions. It is apparent 
that from the literature that financial literacy is not well defined. For example and as mentioned previously, the Blue Ribbon Committee provided a basic, definition, but without specific details. Both the Financial Executives Institute (FEI) and Deloitte have developed survey instruments aimed at financial literacy.

While attempting to measure the same competencies, the FEI and Deloitte instruments have very few questions in common with the Shipper and Weil instrument. Until there is some consensus as to specific knowledge (accounting concepts and techniques, audit committee responsibilities, internal controls, etc.) that represent financial literacy, and practical guidance as to how to evaluate financial literacy, audit committees and boards will need to use professional judgment in determining the most appropriate way to measure financial literacy considering the composition and expertise of the board members.

Table 1

Directors, U. of Chicago MBA Students, Undergraduate Students Ranked by Directors' Percent Correct (Ascending) Aggregated Results

\begin{tabular}{|c|c|c|c|c|}
\hline Q. & Topic (Classification) & $\begin{array}{c}\text { Directors* } \\
\text { (25 items) } \\
\text { Correct }\end{array}$ & $\begin{array}{c}\text { MBA** } \\
\text { (13 Items) } \\
\text { Correct }\end{array}$ & $\begin{array}{c}\text { UG*** } \\
(25 \text { items })\end{array}$ \\
\hline$\underline{23}$ & Income Manipulation (AC) & $5 \%$ & & $10 \%$ \\
\hline$\overline{6}$ & Restructuring Charges (Adv) & $6 \%$ & & $3 \%$ \\
\hline$\underline{\mathbf{1 7}}$ & Purchase Commitments (MBA) & $9 \%$ & $30 \%$ & $0 \%$ \\
\hline 21 & SEC Mandate: Audit Comm (AC) & $11 \%$ & & $7 \%$ \\
\hline$\underline{24}$ & Materiality (AC) & $12 \%$ & & $3 \%$ \\
\hline$\underline{\underline{22}}$ & Barter Transactions (Adv) & $14 \%$ & & $33 \%$ \\
\hline$\underline{\overline{14}}$ & Deferred Income Taxes (MBA) & $16 \%$ & $13 \%$ & $17 \%$ \\
\hline$\overline{\mathbf{3}}$ & Special Purpose Entities (AC) & $17 \%$ & & $13 \%$ \\
\hline$\underline{16}$ & Derivatives (Adv) & $26 \%$ & & $10 \%$ \\
\hline$\overline{13}$ & Stock Options (Adv) & $27 \%$ & & $67 \%$ \\
\hline$\underline{12}$ & Operating Leases (MBA) & $28 \%$ & $83 \%$ & $33 \%$ \\
\hline$\overline{4}$ & LIFO Accounting (MBA) & $28 \%$ & $50 \%$ & $13 \%$ \\
\hline$\overline{10}$ & Issue Shares for I.O.U. (Adv) & $30 \%$ & & $23 \%$ \\
\hline$\underline{9}$ & Statement of Cash Flows (MBA) & $33 \%$ & $53 \%$ & $10 \%$ \\
\hline$\underline{\mathbf{2 5}}$ & Mandatory Rept: Audit Com (AC) & $34 \%$ & & $47 \%$ \\
\hline$\overline{19}$ & Reserves (Adv) & $36 \%$ & & $7 \%$ \\
\hline 18 & Reserves (Adv) & $36 \%$ & & $27 \%$ \\
\hline 20 & Retained Earnings (MBA) & $39 \%$ & $50 \%$ & $30 \%$ \\
\hline 5 & Impairment of PP\&E (MBA) & $40 \%$ & $33 \%$ & $17 \%$ \\
\hline 2 & Goodwill (MBA) & $45 \%$ & $37 \%$ & $40 \%$ \\
\hline 7 & Gains \& Losses on PP\&E (MBA) & $48 \%$ & $47 \%$ & $40 \%$ \\
\hline 8 & Equity Method (MBA) & $48 \%$ & $97 \%$ & $60 \%$ \\
\hline 1 & Marketable Securities (MBA) & $59 \%$ & $57 \%$ & $70 \%$ \\
\hline 15 & Asset Impairment (MBA) & $72 \%$ & $60 \%$ & $63 \%$ \\
\hline 11 & Deferred Revenue (MBA) & $\underline{74 \%}$ & $\underline{63 \%}$ & $\underline{87 \%}$ \\
\hline & Averages & $\overline{32 \%}$ & $\overline{53 \%}$ & $\overline{29 \%}$ \\
\hline $\mathrm{AC}=$ & Committee & & & \\
\hline $\mathrm{Adv}$ & anced Accounting & & & \\
\hline $\mathrm{MB}$ & A accounting class material & & & \\
\hline$* \mathrm{~N}$ & 66 directors and officer & & & \\
\hline$* * \mathrm{~N}$ & p 30 students- University of Chicag & & & \\
\hline & Undergraduate Accounting and Fi & & & \\
\hline
\end{tabular}


Table 2

Results for MBA Questions Only Directors' Results in Ascending Order

\begin{tabular}{|c|c|c|c|c|}
\hline $\begin{array}{l}\text { Q. } \\
\text { Nr. }\end{array}$ & Topic & $\begin{array}{c}\text { Directors } \\
\text { Correct } \\
\underline{\%}\end{array}$ & $\begin{array}{c}\text { MBA } \\
\text { Correct } \\
\frac{\%}{\underline{y}}\end{array}$ & $\begin{array}{c}\text { UG } \\
\text { Correct } \\
\%\end{array}$ \\
\hline$\underline{17}$ & Purchase Commitments & $9 \%$ & $30 \%$ & $0 \%$ \\
\hline$\overline{14}$ & Deferred Income Taxes & $16 \%$ & $13 \%$ & $17 \%$ \\
\hline$\underline{12}$ & Operating Leases & $28 \%$ & $83 \%$ & $67 \%$ \\
\hline$\overline{4}$ & LIFO Accounting & $28 \%$ & $50 \%$ & $13 \%$ \\
\hline$\underline{9}$ & Statement of Cash Flows & $33 \%$ & $53 \%$ & $10 \%$ \\
\hline$\overline{2} 0$ & Retained Earnings & $39 \%$ & $50 \%$ & $30 \%$ \\
\hline 5 & Impairment of PP\&E & $40 \%$ & $33 \%$ & $17 \%$ \\
\hline 2 & Goodwill & $45 \%$ & $37 \%$ & $40 \%$ \\
\hline 7 & Gains \& Losses, PP\&E & $48 \%$ & $47 \%$ & $40 \%$ \\
\hline 8 & Equity Method & $48 \%$ & $97 \%$ & $60 \%$ \\
\hline 1 & Marketable Securities & $59 \%$ & $57 \%$ & $70 \%$ \\
\hline 15 & Asset Impairment & $72 \%$ & $60 \%$ & $63 \%$ \\
\hline \multirow[t]{2}{*}{11} & Deferred Revenue & $74 \%$ & $63 \%$ & $87 \%$ \\
\hline & Averages & $42 \%$ & $52 \%$ & $43 \%$ \\
\hline
\end{tabular}

Table 3

Results For Non-MBA Questions

Directors and Undergraduates Ascending Order (\# correct)

\begin{tabular}{|c|c|c|c|c|}
\hline Q. & Non-MBA Questions & & $\begin{array}{c}\text { Directors } \\
\text { Correct }\end{array}$ & $\begin{array}{c}\text { UG } \\
\text { Correct } \\
\end{array}$ \\
\hline Nr. & Topic & $\underline{\text { Classif }}$ & $\%$ & $\underline{\%}$ \\
\hline$\underline{\underline{23}}$ & $\overline{\text { Income Manipulation }}$ & Advanced & $\overline{5 \%}$ & $1 \overline{0 \%}$ \\
\hline$\underline{6}$ & Restructuring Charges & Advanced & $6 \%$ & $3 \%$ \\
\hline $2 \overline{1}$ & SEC Mandate to Audit Com & Audit Com & $11 \%$ & $7 \%$ \\
\hline$\underline{24}$ & Materiality & Audit Com & $12 \%$ & $3 \%$ \\
\hline$\underline{22}$ & Barter Transactions & Advanced & $14 \%$ & $33 \%$ \\
\hline$\overline{\mathbf{3}}$ & Special Purpose Entities & Audit Com & $17 \%$ & $13 \%$ \\
\hline 16 & Derivatives & Advanced & $26 \%$ & $10 \%$ \\
\hline 13 & Stock Options & Advanced & $27 \%$ & $67 \%$ \\
\hline 10 & Issue Shares for I.O.U. & Advanced & $30 \%$ & $23 \%$ \\
\hline$\underline{25}$ & Mandatory Report Audit Com & Audit Com & $34 \%$ & $47 \%$ \\
\hline$\overline{19}$ & Reserves & Advanced & $36 \%$ & $7 \%$ \\
\hline \multirow[t]{2}{*}{18} & Reserves & Advanced & $36 \%$ & $27 \%$ \\
\hline & Average (12 items) & & $21 \%$ & $21 \%$ \\
\hline
\end{tabular}

Table 4

Averages for Directors and Undergraduates

Aggregated and Disaggregated Median Scores (\% Correct)

\begin{tabular}{ccccc}
\hline & $\underline{\text { Directors }}$ & $\underline{\text { MBA }}$ & $\underline{\text { UG }}$ & \\
Aggregated & $28 \%$ & $51 \%$ & $77 \%$ & $60 \%$ \\
Disaggregated & $58 \%$ & $77 \%$ & \\
\hline
\end{tabular}

*Mean values (\# correct) for all undergraduates are 56.7\% (disaggregated) and 23.5\% (aggregated) and for the top 30 undergraduates the mean values are $23.5 \%$ for all students (disaggregated) and $49.4 \%$ (aggregated). 


\section{AUTHOR INFORMATION}

Dr. Don E. Giacomino, CPA is Professor of Accounting and the Donald and Beverly Flynn Chair Holder at Marquette University. He earned a DBA from the University of Kentucky and the MBA from the University of Montana. Giacomino has published a Management Accounting text and over 50 refereed articles in academic and professional journals, including Advances in Accounting, Journal of College Teaching and Learning, Journal of Accountancy, the CPA Journal, Issues in Accounting Education, International Business and Economics Research Journal and Journal of Managerial Issues. He serves on the Board and Executive Committee of the Wisconsin Institute of CPAs

Joseph Wall, Assistant Professor of Business Administration, Carthage College Managing Member, Ideas in Motion LLC jwall@carthage.edu joseph.micahel.wall@gmail.com. Joseph Wall is an assistant professor of business administration at Carthage College. He also serves as a Managing Member of Ideas In Motion LLC, a proprietary securities trading firm. He earned his M.B.A. from Marquette University in 2006 and his B.S. in Engineering in 1993 from Purdue University. He has over 15 years of experience in securities analysis, risk metric development, and international arbitrage modeling.

Dr. Michael D. Akers, CPA, CIA, CMA, CFE, CBM is the Charles T. Horngren Professor of Accounting and Chair, Department of Accounting. He earned his doctoral degree at the University of Mississippi and his MBA at the University of Louisville. In addition to serving on the editorial advisory board of two journals, he has authored more than 50 articles in academic and professional journals. He currently serves on the Audit Committee and Board of Directors of two publicly traded companies.

\section{REFERENCES}

1. Baker, J. (1945). Directors and their functions; a preliminary study. Boston: Division of research, Graduate school of business administration, Harvard University.

2. Barnhart, Scott W. and Stuart Rosenstein. (1998). Board Composition, Managerial Ownership, and Firm Performance: An Empirical Analysis, Financial Review 33: 1-36.

3. Baysinger, B.D. \& H. Butler. (1985). Corporate Governance and the Board of Directors: Performance Effects of Changes in Board Composition. Journal of Law, Economics, and Organization 1: 101-134.

4. Blue Ribbon Committee on Improving the Effectiveness of Corporate Audit Committees. (1999). Report and Recommendations of The Blue Ribbon Committee on Improving The Effectiveness of Corporate Audit Committees. The New York Stock Exchange and The Association of Securities Dealers. pp. 1-72.

5. Coates, Douglas J., M. Laurentius Marais and Roman L. Weil. (2007), “Audit Committee Financial Literacy: A Work in Progress," Journal of Accounting, Auditing \& Finance. Vol. 22 Issue 2, pp. 175-194.

6. Douglas, W. (1934). "Directors who do not direct" Harvard Law Review, Vol. 47, pp. 1305-1334, June 1934.

7. General Accounting Office. (1989). "CPA Audit Quality: Status of Actions Taken to Improve Auditing and Financial Reporting of Public Companies," at 5 (GAO/AFMD-89-38). (March).

8. Hills, Roderick M. and Roman L. Weil. (2004). "Nuts and Bolts Guidance For Audit Committees," The Corporate Board. (September/October). pp. 1-6.

9. Koontz, H. (1967). The Board of Directos and Effetive Management. New York: McGraw-Hill Book Company.

10. Mace, M. (1971). Directors: Myth and Reality. Boston: Division of research, Graduate School of Business Administration, Harvard University.

11. Morse, Gardiner. (2004). “Audit Committees Can’t Add.” Harvard Business Review, (May), Vol. 82 Issue 5, pp. 21-24.

12. National Commission on Fraudulent Financial Reporting. (1987). Report of the National Commission on Fraudulent Financial Reporting. (October). pp. 1-192.

13. Song, Jihe and Windram, Brian, (November 14, 2000). "Benchmarking Audit Committee Effectiveness in the UK". Available at SSRN: http://ssrn.com/abstract=249865 or DOI: 10.2139/ssrn.249865

14. Weil, Roman L. (2006). Directors' Consortium Audit Committee Issues. (August 24). Chicago Graduate School of Management. pp. 1-82. 